\title{
Condemning corruption while condoning inefficiency: an experimental investigation into voting behavior
}

\author{
Paulo Arvate ${ }^{1} \cdot$ Sergio Mittlaender $^{2}$ (D)
}

Received: 14 December 2016/ Accepted: 26 April 2017/Published online: 17 May 2017

(C) The Author(s) 2017. This article is an open access publication

\begin{abstract}
This article reports results from an economic experiment that investigates the extent to which voters punish corruption and waste in elections. While both are responsible for reductions in voters' welfare, they are not necessarily perceived as equally immoral. The empirical literature in political agency has not yet dealt with these two dimensions of voters' choice calculus. Our results suggest that morality and norms are indeed crucial for a superior voting equilibrium in systems with heterogeneous politicians: while corruption always is punished, self-interest alone-in the absence of norms-leads to the acceptance and perpetuation of waste and social losses.
\end{abstract}

Keywords Corruption $\cdot$ Waste $\cdot$ Elections $\cdot$ Experiment

JEL Classification C91 - D72 - H23 - H72

\section{Introduction}

Elections serve two main functions in representative democracies: they allow voters to select the politicians that best represent their preferences and to punish incumbents that misbehave. Theory (Barro 1973; Ferejohn 1986; Persson and Tabellini 2002), corroborated

Electronic supplementary material The online version of this article (doi:10.1007/s11127-017-0452-x) contains supplementary material, which is available to authorized users.

Sergio Mittlaender

Mittlaender@mpisoc.mpg.de

Paulo Arvate

Paulo.Arvate@fgv.br

1 São Paulo School of Business Administration, Center for Applied Microeconometrics (C-Micro), Getúlio Vargas Foundation, Rua Itapeva 474, São Paulo 01332-000, Brazil

2 Max Planck Institute for Social Law and Social Policy, Amalienstraße 33, 80799 Munich, Germany 
by evidence (Ferraz and Finan 2008, 2011; Winters and Weitz-Shapiro 2013), reveals that voters punish corrupt incumbents whenever they have access to credible and reliable information about acts of corruption. Politicians, however, misbehave both when they engage in corruption and when they waste public resources because of their mismanagement or misuse (Bandiera et al. 2009). Waste and corruption are both responsible for reducing voters' welfare, but these may not be perceived as equally unacceptable. Voters might be willing to condemn corruption, but also to condone waste.

There are different reasons why voters might punish politicians that are corrupt, but not those that waste public resources. Inefficient regulation, taxation and redistribution, for instance, create distortions in markets but often lead to positive outcomes valued by voters (Besley and Coate 1998; Acemoglu 2001; Besley and Smart 2007). At the same time, voters might blame waste on "the system", and be unable to attribute responsibility for it to any specific politician. Lastly, waste and corruption might not induce the same moral outrage, as only corruption leads to illicit enrichment of politicians. In an experiment, we exclude the first two reasons for voters to condone waste in order to study how far voters are willing to punish, in elections, waste and corruption leading to the same loss of welfare.

The recent Brazilian case involving the giant oil-company Petrobrás-pivotal to the recent political crisis that engulfed the country-is representative of this situation in the real world. The company is partially owned by the state, which appoints several directors and its chairman, which included Brazilian president Dilma Rousseff prior to her election. In 2014, the audited losses occasioned by corruption involving Petrobrás's activities amounted to around 6 billion Reais; losses owing to misuse and mismanagement of resources were seven times larger, at around 44 billion Reais. ${ }^{1}$ While arguments against corruption were widespread in the race, those involving waste were scarce, but it is notoriously difficult to distinguish the impact of waste and corruption on electoral outcomes as voters might have been unable to attribute blame for waste to any specific politician, or might have received different amounts of credible information regarding corruption (which often leads to legal prosecution) and waste (which rarely does).

Recent models in political agency take into account the heterogeneity among politicians and show that those who misbehave can, in certain situations, survive reelections if voters seek to maximize individual gains (Besley 2006; Besley and Smart 2007). Politicians differ from each other in competence and their skills in bargaining over the distribution of public funds. Providing pork to their constituents is a preponderant component of their competence in the political economy literature (see, e.g., Coate and Morris 1995). A politician responsible for embezzlement or waste of public funds can survive reelections if she delivers more pork to her constituents than other politicians that do not misbehave (see, e.g., Karahan et al. 2006). In this case, voters face a tradeoff between what is best for themselves and what is best for society, and elections might fail to at the same time select the politicians that best represent voters' interests and to punish those that misbehave.

We investigate voters' behavior when this tradeoff is present, and when voters' decisions are not trivial. When the politician that is the most skilled one does not misbehave, then voters are unequivocally expected to select this candidate, and no problem emerges. The same is true when the politician who misbehaves is not skilled in

1 As in the audited balance sheet of the company for the year 2014 (by Mckinsey \& Co.), released on April $22,2015$. 
bringing home the bacon: voters are then unequivocally expected to punish her in reelections. We consider the situation in which voters have to choose between a politician who provides them with more pork, but misbehaves (being responsible either for waste or corruption), and another competitor that provides them with less pork, but does not misbehave.

Voters may condone politicians that misbehave because of the absence of a norm that they ought not do it, and that can allow voters to coordinate their actions. A norm, if agreed and accepted by the majority of the voters is apt to induce them to reject those politicians even when monitoring and sanctioning by other citizens is impossible: since the vote is secret, voters do not observe the votes of the others, and are bound only by their conscience. We therefore study, in addition, how far such a non-binding norm, agreed upon by the majority of the voters, allows them to overcome their self-interest and to consider the social interest when casting the ballot.

Our results reveal, firstly, that voters overwhelmingly condemn corrupt politicians, almost completely eliminating their electoral chances, but very often condone politicians who only create waste. Unlike previous lab experiments that investigate corruption in the bribe game, and which found weak or no evidence for the moral costs of corruption (Abbink and Hennig-Schmidt 2006; Barr and Serra 2009), our game includes the negative externality of corruption in elections and confirms that corruption is strongly punished. In contrast, the results reveal that voters often condone politicians that impose the same welfare loss because of waste of public funds. Lastly, a norm that is accepted by most of the citizens allows voters to coordinate their actions and encourages them to consider the interests of the whole society, and not only that of their district.

Results from lab experiments of corruption have been found to be generalizable outside the lab and, to some extent, also across cultures (Barr and Serra 2010; Armantier and Boly 2012, 2013), providing support for their external validity. While cultural differences might affect the propensity of individuals to punish corruption, individuals engage in that type of punishment in a wide variety of countries (Cameron et al. 2009; Barr and Serra 2010). Experimental evidence is therefore capable of providing meaningful insights into voting behavior and into the effect of norms, as well as useful recommendations for policymakers.

The type of coordination created by norms can be achieved, in reality, by the individuals themselves, backed up by NGOs and other actors, and need not be enforced by the state or by the law. A willingness to abide by a legitimate norm exists even in secret ballots, when punishment for deviation is not possible because the vote is secret and, hence, not observable to others. However, for this norm to be effective, voters need to have information on the amounts of waste created by the activities of different politicians. The provision of information concerning amounts embezzled is widely encouraged by the law and by different political and social organizations. We argue that equally or perhaps even more important for the welfare of voters is information concerning waste, so that possibly existing norms that waste ought not to be condoned can be effective.

The paper is structured in the following way. In Sect. 2, theoretical and empirical studies of the role of elections in punishing politicians who misbehave are reviewed together with the existing experimental studies of corruption, which commonly focus on the bribe game, and not on elections. Section 3 presents the experimental study, the implemented game and treatments, and hypotheses under scrutiny. The results are presented and analyzed in Sects. 4 and 5 concludes. 


\section{Related literature}

The role of elections in replacing corrupt politicians is explained in theoretical models. The political agency model, firstly developed by Barro (1973) and Ferejohn (1986), considers politicians as agents responsible for taking actions that are not observable to voters (Persson and Tabellini 2002). Since those models assume that politicians do not to differ from each other, they predict that voters will always punish corrupt incumbents if they have access to credible and reliable information on acts of corruption. ${ }^{2}$

Politicians, however, differ from each other in reality, and this heterogeneity brought the selection function of elections to the forefront of the analysis (Galasso and Nannicini 2017). Fearon (1999) showed that the equilibrium in pure moral hazard models is not robust to the introduction of candidate heterogeneity when voters' payoffs depend on differences between candidates. Besley (2006) distinguished between good (congruent) and bad (incongruent) politicians and showed how the selection and the disciplinary functions of elections have to be weighed when assessing the effect of improved information on voters' welfare. ${ }^{3}$

In case of a legislative body empowered with the task of distributing public resources between municipalities or states, elected representatives have incentives to bring home as much pork as possible for the benefit of their constituents. In attempting to maximize their own gains, voters fail to internalize the impact that such pork-barrel spending has on other districts, and politicians seeking to be reelected have incentives to maximize spending in their electoral districts, creating thereby a suboptimal allocation of resources and an overall loss of welfare. Aidt and Shvets (2012) studied the incentive effect of reelections on the allocation of public spending and showed how reelection induces representatives to deliver more pork to their districts and exacerbates the common-pool problem studied initially by Weingast et al. (1981). ${ }^{4}$

We explore a political failure that emerges when candidates differ from each other in their pork-barreling skills and in the amounts of resources embezzled or wasted, and where the number of candidates is not infinite but rather limited in each district. In this case, voters often face a tradeoff between voting for a politician who can deliver more pork at a cost to society and a politician who, while delivering less pork, does not cause such a loss. The study of this subset of political failures may shed light on the limitations of elections in providing incentives for elected agents to refrain from corruption and mismanagement of public funds, and for voters to be able to eliminate, in secret-ballot elections, the welfare loss that such acts create.

\footnotetext{
2 In identifying the secrecy of corruption as the main cause of such phenomenon, the literature has focused its policy recommendations in terms of improved transparency and accountability (Ferraz and Finan 2008, 2011; Kolstad and Wiig 2016; but see Escaleras and Lin 2010), stricter enforcement of crimes involving corruption (Fisman and Miguel 2007), better wages and benefits for politicians (Azfar and Nelson 2007), and staff-rotation measures (Abbink 2004).

3 "The idea that potential politicians differ in their competence is no different from a standard assumption in labor market models that individuals have specific skills so that they will perform better or worse when matched in certain jobs... If competence differs, then an important role of elections is to pick competent politicians and to remove from office those who are demonstrably out of their depth." (Besley 2006, p. 48).

4 A political system that encourage legislators to bring home more pork might encourage voters to monitor them (Kunicová and Rose-Ackerman 2005), but nothing guarantees that voters will not reward, instead of punish, those who are best at bringing home the bacon independent of the high costs, in terms of inefficiency and waste, that such pork-barrel spending might create for society as a whole.
} 
The experimental literature on corruption that emerged in recent decades investigates the determinants of corrupt behavior and the efficacy of anti-corruption measures in the bribe game. Less attention has been devoted to how voters react to corruption and waste in secret-ballot elections. Existing experiments of corruption regularly involve two or more players in a game in which the first player takes the role of the briber and the second one of the public official (Abbink et al. 2000, 2002; Abbink 2004). In this setting, variations in politicians' salaries did not affect observed levels of bribes (Abbink et al. 2000), but staff rotation measures (Abbink 2004), liability for bribe-takers with no liability for bribe-givers (Abbink et al. 2014), and monetary rewards for whistleblowers (Abbink and Wu 2017) reduced collusive bribery. The study of Abbink et al. (2002) also introduced the negative externality into the bribe in the game, and found no evidence that individuals consider the harm they cause to other subjects when deciding whether to offer or accept a bribe. Büchner et al. (2008) further show that, in multi-dimensional bidding contests, bidders that know of the existence of a corrupt and anonymous bureaucracy engage in active bribing.

We contribute to the literature by investigating, firstly, to what extent voters punish corruption and waste in secret-ballot elections. Secondly, we study the impact of a shared and agreed upon norm prescribing that one shall not vote for politicians who misbehave in either of those dimensions. In the experiment, corruption and waste created losses for voters and, hence, capture the negative externality that those acts have, in reality, inside the game.

\section{Experimental design}

We implement a finitely repeated voting game in which a politician skilled in porkbarreling runs against a less skilled one in each electoral district. The politician with the most votes in each district is elected to represent that district, thus determining the amount of funds it will receive. Between treatments, we manipulate whether the skilled politician is responsible for waste or embezzlement of an equal amount of resources for her personal gain. In both cases, the amount wasted or embezzled is limited, such that skilled politicians still provide more pork to their voters after considering those losses, and the strictly dominant strategy for the voters is always to vote for them.

As detailed below, politicians were real participants who willingly decided to take the role of such representatives after reading the instructions and receiving complete information about the game they would play. Politicians did not make any choice during the game. Voters were the only subjects who had an active role in casting their ballots. Depending on the choice of the voters in each district, the participant in the role of the elected politician earned a fixed salary, plus an amount corresponding to the funds diverted by that type of politician if the politician was a corrupt one.

\subsection{The voting game}

The game involves a fixed national budget $\mathrm{B}=10,000$ and four electoral districts, denoted $n \in N=\{1,2,3,4\}$. All districts have the same two types of politicians running to represent the constituents and five voters each. Candidates receiving the most votes in each district are elected for one period (simple majority voting). The game is repeated for ten periods and participants receive feedback on the number of elected politicians of each type, the amount of social losses created, the earnings in their district, and the earnings of the 
elected politicians (including the amounts embezzled by the type of politician, if corrupt) after each round.

The sequence of actions and events in the voting game is straightforward: voters cast their ballots and election results are announced. The amount of funds that each district receives depends on the type of elected politician, just as do the amounts of funds embezzled or wasted. Politicians are dummy players and do not make any choice in order to prevent any form of strategic interaction between voters and politicians. Therefore, amounts embezzled or wasted depend only on the voters' decision to elect one or the other type of politician. New elections follow, always with the same politicians, and voters can reelect the incumbent or vote for the challenger.

Politician 2 is twice as skilled in bringing funds from the budget to her electoral district as politician 1. If elected, however, politician 2 creates a loss of $25 \%$ of that larger transfer. Therefore, politician 2 can provide voters in the district she represents an amount that is $50 \%$ more than delivered by politician $1 .^{5}$

Let $\alpha_{n} \in\{1,2\}$ denote the skills of politician 1 and 2, respectively, who are elected in district $n$. The amount of public funds $g_{n}$ allocated to each district $n$ from the available budget of 10,000 depends on the skill of the politician representing that district, and on the skill of all other politicians elected in the remaining $n-1$ districts, and is given by:

$$
\begin{aligned}
& g_{n}\left(\text { politician } 1, \alpha_{n-1}\right)=1 \cdot \frac{10,000}{\sum_{n} \alpha_{n}} \\
& g_{n}\left(\text { politician } 2, \alpha_{n-1}\right)=2 \cdot \frac{10,000}{\sum_{n} \alpha_{n}}
\end{aligned}
$$

Voter's $i$ individual payoff $y_{i}$ is given by the amount of funds that her district receives, which is divided equally between the five voters in the district after considering the loss of $25 \%$ of the transfer occasioned by politician 2 .

$$
\begin{gathered}
y_{i, n}\left(\text { politician } 1, \alpha_{n-1}\right)=\frac{1}{5} \cdot \frac{10,000}{\sum_{n} \alpha_{n}} \\
y_{i, n}\left(\text { politician } 2, \alpha_{n-1}\right)=\frac{1,5}{5} \cdot \frac{10,000}{\sum_{n} \alpha_{n}}
\end{gathered}
$$

Since $y_{i, n}($ politician 2$)>y_{i, n}($ politician 1$)$, regardless of how the other districts vote, voting for politician 2 is the strictly dominant strategy for voters in the game in any one period. A district will always earn more funds by electing politician 2 given any possible electoral outcome in the other districts. The outcome is a socially suboptimal Nash equilibrium upon which no district can improve by electing politician 1 .

If all districts elect, in this manner, politician 2, then they all split the available budget equally after the losses of $25 \%$ are deducted. Since all elected politicians are then equally highly skilled in pork-barreling, each district receives 1875 , and each voter earns 375 . In this case, a total loss of 2500 materializes, and only 7500 is distributed across districts. In contrast, if all districts elect politician 1, then they all split the available budget equally and

\footnotetext{
5 When politicians differ in their pork-barreling skills and in the loss of welfare they occasion for voters, several possible combinations of types could arise. We focus on the one that presents a tradeoff for voters, and not on those that do not, as, for example, when a skilled politician who does not create any waste runs against any other type, or when an unskilled politician who creates waste runs against a politician who is better than her in any dimension.
} 
there is no social loss. Since all elected politicians are in this case equally skilled, each of the four districts receives 2500, and each voter in each district earns 500. If some districts elect politician 1, and others elect politician 2, then the ones that elect politician 2 receive $50 \%$ more funds than the ones electing politician 1. In this case, the total amount of resources to be distributed across districts is smaller and proportional to the number of politicians 2 elected.

Politicians who are elected receive a fixed salary of 600 in that period, and participants thus have incentives to be politicians. Politicians who are not elected receive an amount equal to the sum received by voters in that district in that period. This amount is not deducted from the national budget in the experiment in order to make the non-elected politician's earnings equal to the voters' earnings.

\subsection{Treatments}

The experiment involved four treatments. In treatment waste, voters chose between politician 1, "a politician who delivers fewer resources, but who does not create a loss of funds from the budget", and politician 2, "a politician who brings twice as many resources (as politician 1), but who creates a loss equal to $25 \%$ of that amount of funds". The amount of funds lost in the election of politician 2 did not benefit anybody in the experiment, and voters were aware of this fact. Any elected politician, whether type 1 or type 2, always earned a fixed salary of 600 when elected.

In treatment corruption, voters could vote for politician 1, "a politician who brings fewer resources, but who does not divert public funds from the budget for personal gain", or for politician 2, "a politician who brings twice as many resources (as politician 1) but who diverts $25 \%$ of that amount of funds for personal gain". Since politicians did not make any choice in the game, this amount of funds diverted was automatically deducted from the transfer to the district, and added to the earnings of the participant in the role of the corrupt politician whenever she was elected, and voters were aware of these facts. Therefore, participants who decided to be politician 2 earned the public salary of 600 plus the amount embezzled by that type of politician when elected.

In treatment waste with norm, participants took part in a referendum, before playing the game, for the possible institution of a norm that established that "one shall not vote for politicians who create losses of resources from the budget." Participants were informed that if the majority of them voted in favor of the norm, then it would be applied, but not otherwise. There was no sanctioning or monitoring, and participants were aware of this fact. After receiving information on whether the norm was approved or not, participants played the same game as in treatment waste.

In treatment corruption with norm, participants took part in a referendum for the possible institution of a norm that "one shall not vote for politicians who divert resources from the budget." The voting and procedure for the establishment of the norm was exactly the same as in treatment waste with norm. After receiving information on whether the norm was approved or not, subjects played the same game as in treatment corruption.

\subsection{Hypotheses}

Voters willing to maximize their individual gains are predicted to vote for politician 2 in all rounds, and in the socially suboptimal Nash equilibrium of the game all districts are predicted to elect and reelect that politician. Voters' and politicians' earnings, including amounts allocated to each district, and amounts embezzled or wasted depended only on the 
choices of voters, since politicians were dummy players who made no choices. Social losses are expected to be maximal and equal to $25 \%$ of the total amount of public funds available.

Hypothesis 1 Voters will always vote for politician 2 in all treatments.

Voters, however, might be willing to incur a personal cost to punish politicians who are corrupt or who occasion waste. There are two possible reasons for their willingness to condone politicians who create waste, but not politicians who are corrupt. The first one is inequality-aversion (Fehr and Schmidt 1999; Bolton and Ockenfels 2000): corruption creates inequality since the politician enriches herself at the expense of the voters, while waste does not create inequality per se, but only losses for voters. The second one is normative: corruption is immoral while waste is not necessarily perceived as such. Since there is evidence that morality plays a role in the rejection of corruption (Banerjee 2016), we favor the second explanation in our study, which aims at investigating how voters behave when faced with those two types of misbehavior, and not on the cognitive mechanism underlying voter's preferences with respect to waste and corruption.

Hypothesis 2 Voters will vote for politician 2 more often in treatment waste than in treatment corruption.

The norm that one ought not to vote for politicians who create social losses, when agreed upon by the majority of subjects, is apt to create and reinforce moral commitment, and to signal to voters that voting for politician 2, thereby condoning waste or corruption is not acceptable behavior. We therefore expect the norm to discourage voters from subsequently voting for the politician responsible for waste or for corruption. ${ }^{6}$

Hypothesis 3 Voters will vote for politician 2 more often in treatment waste than in treatment waste with norm.

Hypothesis 4 Voters will vote for politician 2 more often in treatment corruption than in treatment corruption with norm.

\subsection{Procedure}

The experiment was implemented on November 3, 4, 5 and 6, 2014, in Itajaí, Brazil (state of Santa Catarina), with one session on each day. It involved 112 participants in four sessions with 28 participants in each (20 voters and 8 politicians), and each subject participated in only one session. It was approved by the Ethics Committee of the São Paulo School of Business Administration (Getúlio Vargas Foundation), designed and implemented with z-Tree (Fischbacher 2007), and participants were recruited through advertisements, emails and posters on campus in the previous weeks. Subjects earned, on average, 20 Reais (around 8 USD), all rounds were paid, and each session lasted only for about $1 \mathrm{~h}^{7}$ There was no follow-up session.

\footnotetext{
6 There is no monitoring or sanctioning, for the vote is secret, and subjects, just as voters in reality, are bound only by their moral and ethical convictions at the time of casting their vote, and of complying with the norm.

${ }^{7}$ Considering the exchange rate in November 2014. R $\$ 20$ for $1 \mathrm{~h}$ is a very substantial amount in Brazil, where the minimum wage was, at that time, $\mathrm{R} \$ 3.25$ per hour, and the average wage was around $\mathrm{R} \$ 11$ per hour.
} 
All sessions took place in the afternoon and in the same computer lab of the university, which had room for up to 60 participants. Since only 28 participants per session were needed, there was an empty terminal between each subject. All subjects who registered for the experiment could take part, and they all provided their written informed consent to participate before the start. The beginning of all sessions had to be delayed to wait for latecomers, and only those participants who arrived after the session had started were not allowed to participate. There was no instance of any anomaly or disruption during the sessions.

Although the primary interest lies in the test of the described hypotheses in round 1 of part 1 of each session (including only independent observations), each treatment involved 10 repeated games to provide insights into the stability of voters' behavior. Each session included two treatments, with and without norm, and the order of implementation was inverted to minimize ordering effects. ${ }^{8}$ Subjects were not informed of the content of the second part before reaching that part of the session. The order of implementation of the treatments is shown in Table 1.

In each session, participants decided before the beginning of the game, but after reading the instructions, which role they would like to take in the experiment. They decided, firstly, if they wanted to be politician or voter. Secondly, and only for those who chose to be politicians, they decided if they wanted to be a type 1 or type 2 politician. Since only eight places were available for politicians in each session, if more than eight participants wanted to be politicians, then eight were selected randomly for that role, and the remaining took the role of voters. Analogously, if more than four participants wanted to be a type 1 or type 2 politician, then only four were selected randomly for that role, and the remaining took the role of voters. Participants chose their role only once, at the beginning of the session, and kept the same role throughout the whole session.

This procedure was explained to the participants in the instructions and again on the screens of the experiment. All interactions and roles were anonymous and voters did not know who were the politicians. A participant who did not choose to take the role of politician was never put in that position, and a participant who did not choose to be politician 2 was never put in that position. In fact, if fewer than eight participants were willing to be politicians, then that session would have to be cancelled, just as if fewer than four participants were willing to be politician 2. As described below, this did not happen, and sufficient numbers of participants were willing to take those roles with full knowledge of their consequences.

Experiments that investigate corrupt decisions randomly allocate subjects to the role of the briber and of the public official, and allow subjects to decide whether to offer a bribe and to accept it, respectively (Abbink et al. 2000, 2002, 2014; Abbink 2004; Abbink and Hennig-Schmidt 2006; Abbink and Wu 2017). We do not allocate subjects randomly to the different roles for ethical and experimental reasons. Firstly, we believe that it is unethical to allocate a participant to the role of a corrupt politician who embezzles resources from the district she represents. Since politicians, in our experiment, did not make any active choice after choosing their role, random assignment of subjects to that role would force a subject to be corrupt. Secondly, a participant who would have been randomly assigned to that role would not have made any active choice in the

\footnotetext{
8 The second parts of sessions 2 and 4 suffered from the fact that subjects will remember the norm after playing under it in part 1 , even if they were told that the norm was not valid anymore in part 2 . We still keep that part of those sessions in the design for reasons of symmetry, although they are not important for the hypothesis under scrutiny.
} 
Table 1 Order of implementation of treatments

\begin{tabular}{lll}
\hline & Part 1 & Part 2 \\
\hline Session 1 & Waste & Waste with norm \\
Session 2 & Waste with norm & Waste \\
Session 3 & Corruption & Corruption with norm \\
Session 4 & Corruption with norm & Corruption \\
\hline
\end{tabular}

experiment for which she could be blamed, and voters would not have a moral reason to punish her. If, however, a participant intentionally chose to take that role, with full knowledge of the game, then it is not unethical to allow her to play in that role, and voters have a moral reason to punish her.

This unorthodox experimental design, adopted for these two reasons, did not affect the voters' choice because politicians made no choices during the experiment, being only dummy players with no strategic interaction between voters and politicians. Therefore, self-selection into that role did not affect voters' behavior, and is not a concern for the hypotheses under study, which concern only voters' choices. Self-selection could, however, still induce a change in the composition of the pool of voters if subjects with certain unobserved characteristics were more inclined to self-select to be politicians rather than voters. Inequality-averse individuals (Fehr and Schmidt 1999; Bolton and Ockenfels 2000), for instance, could be more inclined to choose to be politicians rather than voters. In the design of the experiment, however, eight places for politicians were available in all treatments and, hence, if this change in the pool indeed occurred, then it occurred equally in all treatments, and would not affect comparisons between them. All hypotheses under scrutiny concern differences in voters' behavior across treatments. Furthermore, if certain subjects were more inclined to volunteer to be, for instance, a corrupt politician rather than a politician who creates waste, then only four, in all treatments, were chosen randomly for that role, and all subjects exceeding that number were allocated to the role of voters, leaving the pool of voters unaltered across treatments.

Lastly, we take advantage of the fact that, as reported in Table 2, more subjects wanted to be politicians than the number of slots available for that role. That fact allows us to compare the voting behavior of those subjects who self-selected to be politicians, but who were subsequently allocated to be voters with the voting behavior of those subjects who always wanted to be voters. We cannot accept the hypothesis that their voting behavior differs. ${ }^{9}$

Participants received written instructions (see electronic supplementary material) including a table with how much they, and each other district, would earn depending on the politician elected in their district and in all other districts. Only five outcomes were possible, ranging from one where no district elected politician 2 to one where all districts elected politician 2. At the end of the experiment, points were converted into money, subjects were paid in closed envelopes, and then left the room one at a time.

\footnotetext{
9 Vote for politician 2, voters who wanted to be politician $(\mathrm{N}=31)$ versus voters who wanted to be voters $(\mathrm{N}=49)$, Fischer's exact, $p$ value $=0.8$.
} 
Table 2 Percentage of participants willing to take each role in each session (part 1)

\begin{tabular}{lll}
\hline & Politicians (\%) & Politician 2 (\%) \\
\hline Waste & $18 / 28(64)$ & $8 / 18(44)$ \\
Waste with norm & $14 / 28(50)$ & $4 / 14(28)$ \\
Corruption & $15 / 28(53)$ & $7 / 15(47)$ \\
Corruption with norm & $16 / 28(57)$ & $5 / 16(31)$
\end{tabular}

\section{Results}

The subject pool was reasonably diverse: the average age of participants was 29 years, with a slight majority (55\%) of females (average age in Brazil is 32 years, with $52 \%$ females). The majority of participants had a job (61\%), attended a public school $(53 \%$, Brazilian average is around $80 \%$ ), and did not have private health insurance (59\%, compared with an average of $67 \%$ in that region of Brazil). The obtained sample is therefore quite representative of the population of that region, with, however, a greater predominance of subjects having a private schooling background.

\subsection{Willingness to be politicians, politician types and voting for the norm}

A slight majority of participants choose to be politicians, as reported in the first column of Table 2, something expected given the fact that politicians could never earn less than voters. Surprising, however, is the percentage of participants who chose to be politicians and who subsequently also chose to be politicians of type 2, reported in the second column. Almost half of the subjects (44\%) chose to be a politician who creates waste. Even more surprising is that $47 \%$ of the subjects decided to be a corrupt politician. These percentages were lower when subjects voted on the adoption of the norm before choosing the role they would like to take (in sessions 2 and 4, where the treatment with norm preceded the one without it). This outcome provides a first insight into the effect the norm had in encouraging individuals to consider the common good, and to change their behavior.

With respect to the vote for or against the norm, only a slight majority of subjects voted in favor of the norm against waste, as reported in Table 3. In contrast, a substantial majority voted in favor of the norm against corruption. While $82 \%$ of them agreed that voters ought not to vote for corrupt politicians 1 under the veil of ignorance (in part 1), only $53 \%$ of them agreed that voters ought not to vote for politicians who create waste (also in part 1). Almost identically, when participants voted on the referendum after having played 10 rounds of the game (in part 2), then $86 \%$ voted in favor of the norm in treatment corruption, and only $61 \%$ in treatment waste.

These differences are statistically significant, as reported in the last row of Table 3 (Fisher's exact test). Both norms could improve voters' welfare equally by preventing public funds from not reaching them, if the norms were respected. However, almost half

Table 3 Percentage of participants voting in favor of the norm

\begin{tabular}{llll}
\hline & Part 1 & Part 2 & Aggregate \\
\hline Waste & $15 / 28(53 \%)$ & $17 / 28(61 \%)$ & $32 / 56(57 \%)$ \\
Corruption & $23 / 28(82 \%)$ & $24 / 28(86 \%)$ & $47 / 56(84 \%)$ \\
Fisher's exact (2-sided) & 0.044 & 0.068 & 0.003 \\
\hline
\end{tabular}


the participants did not see the need for such a norm when self-interested behavior would lead to public funds simply being wasted. In contrast, a substantial majority of subjects saw the need for such a norm when public funds would not be wasted, but would personally benefit the politician. The significant differences in the results from voting for the norm across treatments provide a first insight into individuals' willingness to condone waste, but not corruption.

\subsection{Voting for corrupt and inefficient politicians}

Table 4 reports the number and frequency of votes for politician 2 in the different treatments. The first column reports votes collected only in period 1 of part 1 , when voters did not have any type of information on how other voters decided, and hence considers only independent observations. They provide observations on the tests implemented between treatments. The remaining columns report frequencies that consider further periods, and may shed light on the stability of voter choices in the repeated game, and on the robustness of the results.

We can initially reject the strict rational choice hypothesis that voters will always vote for politician 2, disregarding the waste and corruption associated with it. Voting for politician 2, either in treatment waste or corruption, and either in the presence or absence of the norm, is the strictly dominant strategy for voters. The frequency of votes for politician 2, however, is dramatically distant from the predicted average of $100 \%$, and in the case of corrupt politicians it is, in fact, close to zero.

However, roughly half of the subjects $(45 \%)$ voted for the politician responsible for waste. In contrast, only a minute share of the subjects (10\%) voted for the corrupt politician. Observations collected in the first period of part 1 allow us to implement a nonparametric test of hypothesis 2 , and to examine whether the observed proportion of votes for the politician responsible for waste and corruption are statistically different. In effect, voters were more willing to accept waste than corruption (Fisher's exact test, waste versus corruption, $p$ value $=0.031$ ), providing support for hypothesis 2 : voters are more willing to accept waste than corruption.

Table 4 Frequency of votes for politician 2 by treatment

\begin{tabular}{|c|c|c|c|c|}
\hline \multicolumn{2}{|l|}{ Part 1} & \multicolumn{2}{|l|}{ Part 2} & \multirow[t]{2}{*}{ Total } \\
\hline Period 1 & All 10 periods & Period 1 & All 10 periods & \\
\hline \multicolumn{5}{|l|}{ Waste } \\
\hline $45 \%$ & $48 \%$ & $40 \%$ & $23 \%$ & $35 \%$ \\
\hline $9 / 20$ & $96 / 200$ & $8 / 20$ & $46 / 200$ & $142 / 400$ \\
\hline \multicolumn{5}{|c|}{ Waste with norm } \\
\hline $30 \%$ & $32 \%$ & $25 \%$ & $31.5 \%$ & $32 \%$ \\
\hline $6 / 20$ & $65 / 200$ & $5 / 20$ & $63 / 200$ & $128 / 400$ \\
\hline \multicolumn{5}{|c|}{ Corruption } \\
\hline $10 \%$ & $13 \%$ & $20 \%$ & $18 \%$ & $15 \%$ \\
\hline $2 / 20$ & $26 / 200$ & $4 / 20$ & $39 / 200$ & $62 / 400$ \\
\hline \multicolumn{5}{|c|}{ Corruption with norm } \\
\hline $20 \%$ & $11 \%$ & $15 \%$ & $9 \%$ & $10 \%$ \\
\hline $4 / 20$ & $23 / 200$ & $3 / 20$ & $18 / 200$ & $41 / 400$ \\
\hline
\end{tabular}


This result is rarely described in the literature. Empirical studies most often focus solely on corruption (e.g., Ferraz and Finan 2008, 2011), and do not consider the equally detrimental losses stemming from the misuse, misallocation and mismanagement of public resources that often are attached to distributive politics and pork barreling. Voters vote strategically and do not refrain from electing and reelecting politicians responsible for those losses, but who can bring home the bacon even when they observe the welfare losses and the negative externality attached to their vote.

\subsection{Voting under a norm}

The effect of the norm encouraging regard for the interests of all districts together can be captured within subjects, considering how many of them changed their own vote after the norm was institutionalized, as reported in Table 5. In session 1, nine subjects voted for the politician who created social losses; 11 refused to do so, and therefore voted for politician 1. Of these 11 subjects, all of them voted for politician 1 in part 2, after the norm was established, and did not alter their choice. Of the former nine, five still voted for politician 2 , but four changed their behavior and voted for politician 1 .

The result of McNemar's test of proportions (of the symmetry of the contingency table), in session 1, provides support for hypothesis 3: a norm, agreed by the majority of subjects, reduced the number of votes for politicians who create waste. In session 2 , the test concerns whether "de-institutionalizing" the norm led voters to change their behavior and to accept social losses more often in the absence of the norm than in its presence. This comparison suffers from the fact that subjects retain a memory of the norm even when they are told that the norm is not valid anymore in part 2 . There is, accordingly, no significant evidence that supports the hypothesis that de-institutionalizing the norm will increase acceptance of waste, but point estimates are in this direction. ${ }^{10}$

\subsection{Regression results}

Regression analysis provides a robustness check for the obtained results and allows us to investigate the extent to which individual decisions depend on the decisions of other members of the group, and on the decisions of the other groups. We choose treatment corruption as the baseline because this is the case that has been studied at length in the literature. We then ask if voters are equally, more, or less likely to reject waste in comparison to corruption. Lastly, we study the effect of a norm against corruption, and of a norm against waste in comparison with the baseline. The different indicator variables waste, waste with norm, and corruption with norm indicate whether the observation was collected in the respective treatment (equal to unity) or not (equal to zero).

We estimate three sets of models, using, respectively, data from each individual decision, from each group decision, and from each treatment. Observations are truly independent only in the first period, since in that one, voters' decisions do not depend on how other voters behaved in previous periods. We therefore firstly report regression results that consider only those observations in Table 6. After each round, subjects received information and so could alter their behavior based on those facts. They might, therefore, conform to how other members of the group vote, or to how other groups vote. Evidence

\footnotetext{
${ }^{10}$ The analysis of the effect of the norm on votes for the corrupt politician, in sessions 3 and 4 , suffers from the fact that very few voters accepted that politician in the first place, with or without the norm, and, as a result, not enough observations are available for the test of hypothesis 4 .
} 
Table 5 Effect of the norm on votes for politician 2 (treatment waste)

\begin{tabular}{cll}
\hline Period 1, part 1 & Period 1, part 2 & McNemar \\
\hline $\begin{array}{l}\text { Session 1 } \\
\text { Waste }\end{array}$ & Waste with norm & \\
$45 \%$ & $25 \%$ & $\chi^{2}=4(1)$ \\
$9 / 20$ & $5 / 20$ & $p=0.0455$ \\
Session 2 & & \\
Waste with norm & Waste & \\
$30 \%$ & $40 \%$ & $\chi^{2}=1(1)$ \\
$6 / 20$ & $8 / 20$ & $p=0.3173$ \\
\hline
\end{tabular}

has been reported that individual decisions are influenced by the decisions of others, especially from those inside the individual's own group (Güth et al. 2007; Frey and Meier 2004). We take advantage of this information and include the first, second and third lag of these two variables-group choice and number of type 2 politicians elected-in the regressions that consider observations from the repeated game, and study the extent to which they affect individual choices.

We subsequently consider the decisions of each group in each period as one observation in Table 8. This excludes the dependence between individual decisions and decisions of the other members of the same group (electoral district). We can, therefore, drop the variable Group choice, which enters the previous model. However, observations per group still depend on the impact of the decisions of the other groups; in other words, how each group decided, in each period apart from the first one, may depend on the decisions of the other groups. We therefore keep the variable Number of type 2 politicians and, in the last set of regressions presented in Table 9, we exclude that form of dependence by considering treatment averages.

In the first column of Table 6, we report estimates of the linear model including only those observations collected in the first period of the first part (all independent observations). In the second column, we do the same with a non-linear model (a probit model in which vote $=1$ if the decision is to vote for politician 2 and vote $=0$ if the decision is to vote for politician 1). In the third column, we report regression results from the linear model with all observations collected in part 1 and, hence, for the ten rounds of the treatment. Since each subject took the same decision repeatedly, standard errors are all clustered by subject. In the fourth and last column, we do the same with the probit model.

Voters are substantially more likely to vote for the politician who, instead of being corrupt, simply occasions the same social loss by squandering public resources. The point estimates reveal that voters are, on average, from $35 \%$ to almost $50 \%$ more likely to accept waste than corruption. Regression results provide additional support for the results of the non-parametric tests reported above, and for hypothesis 2 . Regression results further reveal how acceptance of politician 2 by other groups in the previous election induced voters to reject politician 2, and to vote more cooperatively. The first lag of the variable Number of type 2 politicians is weakly significant, but its effect is small. It may point to a reaction of voters against the overall acceptance of politician 2 by others, which encouraged a more conscious and pro-social behavior when others behave less cooperatively.

Moreover, acceptance of politician 2 by the other members of one's own group, in the previous election, increased the vote for politician 2. This effect of the first lag of Group choice is large and significant. It shows how voters' behavior depends on the votes and 
Table 6 Individual results

\begin{tabular}{|c|c|c|c|c|}
\hline & \multicolumn{4}{|c|}{ Dependent variable: vote for politician 2} \\
\hline & $\begin{array}{l}\text { (1) } \\
\text { OLS period } 1\end{array}$ & $\begin{array}{l}(2) \\
\text { Probit period } 1\end{array}$ & $\begin{array}{l}(3) \\
\text { OLS part } 1\end{array}$ & $\begin{array}{l}(4) \\
\text { Probit part } 1\end{array}$ \\
\hline Waste & $\begin{array}{l}0.35 * * \\
(0.14)\end{array}$ & $\begin{array}{l}0.39 * * * \\
(0.15)\end{array}$ & $\begin{array}{l}0.46 * * * \\
(0.16)\end{array}$ & $\begin{array}{l}0.49 * * * \\
(0.15)\end{array}$ \\
\hline Corruption with norm & $\begin{array}{l}0.10 \\
(0.14)\end{array}$ & $\begin{array}{l}0.13 \\
(0.15)\end{array}$ & $\begin{array}{l}-0.06 \\
(0.06)\end{array}$ & $\begin{array}{l}-0.08 \\
(0.08)\end{array}$ \\
\hline Waste with norm & $\begin{array}{l}0.20 \\
(0.14)\end{array}$ & $\begin{array}{l}0.24 \\
(0.15)\end{array}$ & $\begin{array}{l}0.26 * * \\
(0.11)\end{array}$ & $\begin{array}{l}0.27 * * \\
(0.11)\end{array}$ \\
\hline Number of type 2 politicians $\mathrm{t}_{\mathrm{t}-1}$ & $\begin{array}{l}- \\
-\end{array}$ & $\begin{array}{l}- \\
-\end{array}$ & $\begin{array}{l}-0.08 * \\
(0.04)\end{array}$ & $\begin{array}{l}-0.07 * \\
(0.04)\end{array}$ \\
\hline Number of type 2 politicians $\mathrm{t}_{\mathrm{t}-2}$ & $\begin{array}{l}- \\
-\end{array}$ & $\begin{array}{l}- \\
-\end{array}$ & $\begin{array}{l}-0.05 \\
(0.04)\end{array}$ & $\begin{array}{l}-0.05 \\
(0.03)\end{array}$ \\
\hline Number of type 2 politicians $_{t-3}$ & - & - & $\begin{array}{l}-0.02 \\
(0.04)\end{array}$ & $\begin{array}{l}-0.02 \\
(0.03)\end{array}$ \\
\hline Group choice $_{t-1}$ & $\begin{array}{l}- \\
-\end{array}$ & - & $\begin{array}{l}0.22 * * * \\
(0.07)\end{array}$ & $\begin{array}{l}0.19 * * * \\
(0.06)\end{array}$ \\
\hline Group choice $_{\mathrm{t}-2}$ & $\begin{array}{l}- \\
-\end{array}$ & $\begin{array}{l}- \\
-\end{array}$ & $\begin{array}{l}0.11 \\
(0.08)\end{array}$ & $\begin{array}{l}0.09 \\
(0.07)\end{array}$ \\
\hline Group choice $_{t-3}$ & - & - & $\begin{array}{l}0.02 \\
(0.08)\end{array}$ & $\begin{array}{l}0.01 \\
(0.06)\end{array}$ \\
\hline Period & $\begin{array}{l}- \\
-\end{array}$ & $\begin{array}{l}- \\
-\end{array}$ & $\begin{array}{l}0.02 \\
(0.01)\end{array}$ & $\begin{array}{l}0.02 \\
(0.01)\end{array}$ \\
\hline Constant & $\begin{array}{l}0.10 \\
(0.10)\end{array}$ & - & $\begin{array}{l}0.03 \\
(0.08)\end{array}$ & - \\
\hline Observations & 80 & 80 & 560 & 560 \\
\hline $\mathrm{R}^{2} /$ pseudo- $\mathrm{R}^{2}$ & 0.0864 & 0.0744 & 0.1755 & 0.1519 \\
\hline $\mathrm{F} / \chi^{2}$ & 2.39 & 7.13 & 4.67 & 44.86 \\
\hline$p$ value & 0.0749 & 0.0680 & 0.0000 & 0.0000 \\
\hline Number (cluster) & - & - & 80 & 80 \\
\hline
\end{tabular}

Standard errors clustered by Subject in models (3) and (4); Average marginal effects reported in models (2) and (4); standard errors clustered by subject

*** $p<0.01$; ** $p<0.05 ; * p<0.1$

behavior of other members of the group. When others revealed their acceptance of politician 2 in the previous election, voters were more likely to do the same and to accept such a politician, thus conforming to group behavior and choices. A similar effect has been observed in experiments studying corruption in collaborative settings, and that reveal how these increase rates of corruption (Weisel and Shalvi 2015).

No statistical evidence is found that the norm encouraged the very few voters who were willing to accept corruption to refrain from it. In the presence of a norm that encouraged voters not to vote for the politician who created waste, point estimates suggest that 
acceptance of such a politician was lower in the presence of the norm, which is consistent with the results reported in Table 5 above, where the norm reduced the frequency of votes for politician 2 from roughly $50 \%$ to around $30 \%$. In order to test whether the norm had an effect and encouraged voters not to vote for politicians who create welfare losses, in comparison to voting for those politicians in the absence of a norm, we test whether the coefficient of waste and waste with norm are statistically different. Table 7 reports the results.

Some supporting evidence exists for hypothesis 3, in models (3) and (4), that the norm encouraged voters to consider the welfare of society as a whole and to refrain from the selfinterested, strictly dominant strategy to vote for politician 2 , and to vote instead for politician 1 .

Table 8 presents different models that consider observations by group: OLS, OLS with bootstrap, multilevel mixed-effects linear regression (Mixed), and the same Mixed model with bootstrap. Four groups participated in each session and, hence, there are 16 observations in total. The last two columns present results from those models, but consider observations from all first ten rounds. Standard errors are clustered by groups in all models that take into account more than just the first period (models 5 and 6).

The results are very similar to those obtained before. Voters are considerably more likely to accept waste than corruption. The point estimates likewise are very similar. Therefore, dependency between each individual decision and the decisions of other individuals in the same group (electoral district) is likely to be unimportant in explaining previous results.

Lastly, we collapse voting by subject, group and treatment, and take only one observation in each treatment per period into account. With four sessions, only four independent observations are available in the first period of the first part and, therefore, not enough observations to estimate that model, as in the previous tables. We consider those four observations in the 10 periods of the first part and, hence, the first four models include 40 observations. We then use all observations, including those from the second part, and therefore have 80 observations in the four final models.

Our robustness checks reveal that the results concerning waste are consistent for any investigation undertaken. There is, therefore, strong support for hypothesis 2 that voters are more likely to elect and reelect a politician who occasions waste than a politician who is corrupt. There is also further support for hypothesis 3 that a norm discourages voters from doing so, and instead fosters prosocial voting and regard for the interests of all voters and districts.

The estimated effects are statistically significant and substantial. While the language used in the instructions was as neutral as possible, avoiding morally loaded terms such as embezzlement or corruption, it was necessary to make it clear to voters that while waste does not benefit the politician (a "loss of funds"), corruption does so (a "diversion of

Table 7 Effect of the norm to discourage acceptance of social losses

\begin{tabular}{lllll}
\hline & $(1)$ & $(2)$ & $(3)$ & (4) \\
& OLS period 1 & Probit period 1 & OLS part 1 & Probit part 1 \\
\hline $\begin{array}{l}\text { Test: waste }=\text { waste } \\
\begin{array}{l}\text { with } \text { norm } \\
\text { (two-sided) }\end{array}\end{array}$ & $\mathrm{F}(1,79)=0.93$ & $\chi^{2}(1)=0.85$ & $\mathrm{~F}(1,79)=3.15$ & $\chi^{2}(1)=3.63$ \\
\hline
\end{tabular}


Table 8 Group results

\begin{tabular}{|c|c|c|c|c|c|c|}
\hline & \multicolumn{6}{|c|}{ Dependent variable: vote } \\
\hline & \multicolumn{4}{|c|}{ Period 1 , part 1} & \multicolumn{2}{|l|}{ Part 1} \\
\hline & $\begin{array}{l}\text { (1) } \\
\text { OLS }\end{array}$ & $\begin{array}{l}(2) \\
\text { Boot OLS }\end{array}$ & $\begin{array}{l}(3) \\
\text { Mixed }\end{array}$ & $\begin{array}{l}\text { (4) } \\
\text { Boot mixed }\end{array}$ & $\begin{array}{l}(5) \\
\text { OLS }\end{array}$ & $\begin{array}{l}(6) \\
\text { Mixed }\end{array}$ \\
\hline Waste & $\begin{array}{l}0.35 * * \\
(0.13)\end{array}$ & $\begin{array}{l}0.35 * * * \\
(0.11)\end{array}$ & $\begin{array}{l}0.35 * * * \\
(0.13)\end{array}$ & $\begin{array}{l}0.35 * * * \\
(0.11)\end{array}$ & $\begin{array}{l}0.46 * * * \\
(0.15)\end{array}$ & $\begin{array}{l}0.46 * * * \\
(0.15)\end{array}$ \\
\hline Corruption with norm & $\begin{array}{l}0.10 \\
(0.13)\end{array}$ & $\begin{array}{l}0.10 \\
(0.10)\end{array}$ & $\begin{array}{l}0.10 \\
(0.11)\end{array}$ & $\begin{array}{l}0.10 \\
(0.09)\end{array}$ & $\begin{array}{l}-0.06 \\
(0.07)\end{array}$ & $\begin{array}{l}-0.06 \\
(0.07)\end{array}$ \\
\hline Waste with norm & $\begin{array}{l}0.20 \\
(0.13)\end{array}$ & $\begin{array}{l}0.20 \\
(0.14)\end{array}$ & $\begin{array}{l}0.20 * \\
(0.11)\end{array}$ & $\begin{array}{l}0.20 \\
(0.14)\end{array}$ & $\begin{array}{l}0.26^{*} \\
(0.14)\end{array}$ & $\begin{array}{l}0.26^{*} \\
(0.14)\end{array}$ \\
\hline Number of type 2 politicians $\mathrm{t}_{\mathrm{t}-1}$ & $\begin{array}{l}- \\
-\end{array}$ & $\begin{array}{l}- \\
-\end{array}$ & $\begin{array}{l}- \\
-\end{array}$ & $\begin{array}{l}- \\
-\end{array}$ & $\begin{array}{l}-0.02 \\
(0.04)\end{array}$ & $\begin{array}{l}-0.02 \\
(0.03)\end{array}$ \\
\hline Number of type 2 politicians $\mathrm{t}_{\mathrm{t}-2}$ & $\begin{array}{l}- \\
-\end{array}$ & $\begin{array}{l}- \\
-\end{array}$ & $\begin{array}{l}- \\
-\end{array}$ & - & $\begin{array}{l}-0.02 \\
(0.03)\end{array}$ & $\begin{array}{l}-0.02 \\
(0.03)\end{array}$ \\
\hline Number of type 2 politicians $s_{t-3}$ & $\begin{array}{l}- \\
-\end{array}$ & $\begin{array}{l}- \\
-\end{array}$ & $\begin{array}{l}- \\
-\end{array}$ & $\begin{array}{l}- \\
-\end{array}$ & $\begin{array}{l}-0.01 \\
(0.03)\end{array}$ & $\begin{array}{l}-0.01 \\
(0.03)\end{array}$ \\
\hline Period & $\begin{array}{l}- \\
-\end{array}$ & $\begin{array}{l}- \\
-\end{array}$ & $\begin{array}{l}- \\
-\end{array}$ & $\begin{array}{l}- \\
-\end{array}$ & $\begin{array}{l}0.02 \\
(0.01)\end{array}$ & $\begin{array}{l}0.02 \\
(0.01)\end{array}$ \\
\hline Constant & $\begin{array}{l}0.10 \\
(0.09)\end{array}$ & $\begin{array}{l}0.10 * \\
(0.06)\end{array}$ & $\begin{array}{l}0.10 \\
(0.09)\end{array}$ & $\begin{array}{l}0.10 * \\
(0.06)\end{array}$ & $\begin{array}{l}0.03 \\
(0.09)\end{array}$ & $\begin{array}{l}0.03 \\
(0.09)\end{array}$ \\
\hline Observations & 16 & 16 & 16 & 16 & 112 & 112 \\
\hline R-squared & 0.38 & 0.38 & - & - & 0.42 & - \\
\hline $\mathrm{F} / \chi^{2}$ & 2.49 & 11.13 & 9.95 & 11.60 & 10.96 & 81.90 \\
\hline$p$ value & 0.110 & 0.0110 & 0.019 & 0.0089 & 0.0001 & 0 \\
\hline Number (cluster) & - & - & - & - & 16 & 16 \\
\hline
\end{tabular}

Models (2) and (4) include 1000 replications of the original sample; standard errors clustered by group (district of the subject) in models (5) and (6)

$* * * p<0.01 ; * * p<0.05 ; * p<0.1$

funds"), and language might have contributed to the estimated effects. Still, a treatment effect of 35 percentage points is very unlikely to result from a framing effect.

\section{Conclusion}

Unlike other lab experiments of corruption that focus on bribes (for reviews, see Abbink 2006; Serra and Wantchekon 2012), we study voters' willingness to punish corruption and waste in secret-ballot elections. Results from the experiment reveal that voters refuse to vote for corrupt politicians when they have access to credible and reliable information on acts of corruption. Corruption emerges as a valence issue, as the vast majority of subjects refused to vote for those politicians at a cost to themselves, and elections largely reduced their electoral chances. Elections indeed served the purpose of eliminating corrupt politicians even when voters must incur a personal cost to do so. 
Table 9 Treatment results

\begin{tabular}{|c|c|c|c|c|c|c|c|c|}
\hline & \multicolumn{8}{|c|}{ Dependent variable: vote } \\
\hline & \multicolumn{4}{|l|}{ Part 1} & \multicolumn{4}{|l|}{ All } \\
\hline & $\begin{array}{l}(1) \\
\text { OLS }\end{array}$ & $\begin{array}{l}(2) \\
\text { Boot } \\
\text { OLS }\end{array}$ & $\begin{array}{l}(3) \\
\text { Mixed }\end{array}$ & $\begin{array}{l}(4) \\
\text { Boot } \\
\text { mixed }\end{array}$ & $\begin{array}{l}(5) \\
\text { OLS }\end{array}$ & $\begin{array}{l}(6) \\
\text { Boot } \\
\text { OLS }\end{array}$ & $\begin{array}{l}(7) \\
\text { Mixed }\end{array}$ & $\begin{array}{l}(8) \\
\text { Boot } \\
\text { mixed }\end{array}$ \\
\hline Waste & $\begin{array}{l}0.35 * * * \\
(0.03)\end{array}$ & $\begin{array}{l}0.35 * * * \\
(0.03)\end{array}$ & $\begin{array}{l}0.35 * * * \\
(0.03)\end{array}$ & $\begin{array}{l}0.35 * * * \\
(0.03)\end{array}$ & $\begin{array}{l}0.20 * * * \\
(0.03)\end{array}$ & $\begin{array}{l}0.20 * * * \\
(0.03)\end{array}$ & $\begin{array}{l}0.20 * * * \\
(0.03)\end{array}$ & $\begin{array}{l}0.20 * * * \\
(0.03)\end{array}$ \\
\hline $\begin{array}{l}\text { Corruption with } \\
\text { norm }\end{array}$ & $\begin{array}{l}-0.01 \\
(0.03)\end{array}$ & $\begin{array}{l}-0.01 \\
(0.03)\end{array}$ & $\begin{array}{l}-0.01 \\
(0.03)\end{array}$ & $\begin{array}{l}-0.01 \\
(0.03)\end{array}$ & $\begin{array}{l}-0.05 * \\
(0.03)\end{array}$ & $\begin{array}{l}-0.05 * * \\
(0.02)\end{array}$ & $\begin{array}{l}-0.05 * \\
(0.03)\end{array}$ & $\begin{array}{l}-0.05 * * \\
(0.02)\end{array}$ \\
\hline Waste with norm & $\begin{array}{l}0.20 * * * \\
(0.03)\end{array}$ & $\begin{array}{l}0.20 * * * \\
(0.03)\end{array}$ & $\begin{array}{l}0.20 * * * \\
(0.03)\end{array}$ & $\begin{array}{l}0.20 * * * \\
(0.03)\end{array}$ & $\begin{array}{l}0.16^{* * *} \\
(0.03)\end{array}$ & $\begin{array}{l}0.16^{* * *} \\
(0.02)\end{array}$ & $\begin{array}{l}0.16^{* * * *} \\
(0.03)\end{array}$ & $\begin{array}{l}0.16^{* * * *} \\
(0.03)\end{array}$ \\
\hline Period & $\begin{array}{l}0.00 \\
(0.00)\end{array}$ & $\begin{array}{l}0.00 \\
(0.00)\end{array}$ & $\begin{array}{l}0.00 \\
(0.00)\end{array}$ & $\begin{array}{l}0.00 \\
(0.00)\end{array}$ & $\begin{array}{l}0.00 \\
(0.00)\end{array}$ & $\begin{array}{l}0.00 \\
(0.00)\end{array}$ & $\begin{array}{l}0.00 \\
(0.00)\end{array}$ & $\begin{array}{l}0.00 \\
(0.00)\end{array}$ \\
\hline Part & $\begin{array}{l}- \\
-\end{array}$ & $\begin{array}{l}- \\
-\end{array}$ & - & - & $\begin{array}{l}-0.09 * * \\
(0.04)\end{array}$ & $\begin{array}{l}-0.09 * * \\
(0.04)\end{array}$ & $\begin{array}{l}-0.09 * * \\
(0.04)\end{array}$ & $\begin{array}{l}-0.09^{* *} \\
(0.04)\end{array}$ \\
\hline Constant & $\begin{array}{l}0.11 * * * \\
(0.03)\end{array}$ & $\begin{array}{l}0.11 * * * \\
(0.03)\end{array}$ & $\begin{array}{l}0.11 * * * \\
(0.03)\end{array}$ & $\begin{array}{l}0.11 * * * \\
(0.03)\end{array}$ & $\begin{array}{l}0.26 * * * \\
(0.04)\end{array}$ & $\begin{array}{l}0.26 * * * \\
(0.04)\end{array}$ & $\begin{array}{l}0.26 * * * \\
(0.04)\end{array}$ & $\begin{array}{l}0.26 * * * \\
(0.04)\end{array}$ \\
\hline Observations & 40 & 40 & 40 & 40 & 80 & 80 & 80 & 80 \\
\hline R-squared & 0.85 & 0.85 & - & - & 0.62 & 0.62 & - & - \\
\hline $\mathrm{F} / \chi^{2}$ & 50.94 & 181.99 & 232.8 & 192.8 & 24.23 & 135.0 & 131.0 & 132.1 \\
\hline$p$ value & 0 & 0 & 0 & 0 & 0 & 0 & 0 & 0 \\
\hline Number (cluster) & - & - & - & - & - & - & - & - \\
\hline
\end{tabular}

Models (2), (4), (6), and (8) include 1000 replications of the original sample; models (3), (4), (7), and (8) are linear mixed effects models

$* * * p<0.01$; ** $p<0.05 ; * p<0.1$

However, when politicians are not corrupt, but rather responsible for wasting public funds, then roughly half the subjects voted for them, and the loss of welfare occasioned by them persisted. Elections and the provision of information on amounts wasted were not enough to minimize the welfare loss predicted in the Nash equilibrium of the game. When considered together with results from the voters' decision to adopt a norm against corruption or waste, results provide support for the hypothesis that while voters strongly reject the first one, they often condone the second one. Further research can shed light on the interaction between the effect of political ideology or party identification on voters' willingness to punish politicians that misbehave, yet that are from a party preferred by the voter, and those from other parties. Mondak (1995) provides evidence that voters value competence, but not necessarily integrity, of politicians from their preferred party.

Future research might also investigate the extent to which corruption and waste influence voter turnout. There is evidence that corruption induces voters to go to polls (Karahan et al. 2006; Escaleras et al. 2012) because of parties' and candidates' greater electioneering efforts to profit from corruption rents (Lacombe et al. 2016). Although waste does not benefit, directly, neither politicians nor voters, specific individuals or firms often profit 
indirectly from it, and waste is, in this case, expected to increase funding and financing of campaigns of politicians responsible for it.

The introduction of a norm, or of a coordinating mechanism voted on by the subjects, induced a change in their electoral behavior, and reduced their willingness to condone waste. They were less likely to fall into the socially suboptimal Nash equilibrium of the game, and social losses were reduced. Those results provide support for our hypothesis that norms induce voters to refrain from voting for politicians who occasion waste, and to consider the interests of the whole society when casting their ballots. Moreover, the results from subjects' lesser willingness to take the role of politicians who occasion waste or who are corrupt, in the presence of a norm, provide additional support for that hypothesis.

The results on the effectiveness of such a norm have policy implications. For norms to be effective, voters need to have information on the acts and amounts involved. While a large body of literature advances the need for transparency and information in order to reduce corruption (e.g., Ferraz and Finan 2008, 2011), we argue that equally important for voters' welfare is transparency concerning the inefficient use of public resources. For instance, even if the stadiums for the last FIFA world cups in South Africa and Brazil were not the targets of corruption, the misallocation and misuse of public funds to build some of them in cities where they were not needed led to large budgetary losses and benefited only the few who live in those cities. Citizens seem to have become aware of this, as the massive demonstrations condemning those expenses that took place before the world cup in Brazil demonstrate. To avoid more waste and to implement a superior equilibrium, more transparency and a clearer assignment of responsibilities for those who make such decisions is needed if voters are to punish politicians who are responsible for wasting public funds.

Finally, the fact that the norm was not supported by sanctions nor by the law suggests that citizens themselves can coordinate their choices and overcome a socially suboptimal equilibrium in elections. Several NGOs have been created to improve the transparency of government spending and to support private actions that reveal this type of information to the public (e.g., Transparency Accountability Initiative, Transparência Brasil). Moreover, legislation that requires the state to make the relevant information public, such as the Federal Funding Accountability and Transparency Act of 2006 in the United States, is capable of improving the capacity of citizens and civil society to select the best politicians and to punish those who misbehave, and for secret-ballot elections to eliminate corruption and waste, and thereby to enhance voters' welfare.

Acknowledgements Open access funding provided by Max Planck Society. The authors would like to thank Rodrigo Bandeira de Mello, Paola Bertoli, Maria Bigoni, Boudewijn Bouckaert, Marco Casari, Bruno Ferman, Andrea Ichino, Rosilene Marcon, Alan Miller, Dennis Müller, Marcos Nakaguma, Thomas Ulen, Sergio Werlang, Christian Zehnder, and participants at the European Public Choice Society 2016, 5th Southern Europe Experimentalist Meeting, 11th Italian Society of Law and Economics, European Master in Law and Economics Midterm Meeting, and São Paulo School of Business Administration Seminar Series for suggestions and contributions to the research project. The authors are also grateful to André Prunner, Giovana Bueno, Gisele Galilea, and Marina Gama for their assistance in implementing the experiment at the University of the Itajaí Valley, in Itajaí, Brazil, in November 2014. Financial support for the experiment was provided by the São Paulo School of Business Administration at Getúlio Vargas Foundation.

Open Access This article is distributed under the terms of the Creative Commons Attribution 4.0 International License (http://creativecommons.org/licenses/by/4.0/), which permits unrestricted use, distribution, and reproduction in any medium, provided you give appropriate credit to the original author(s) and the source, provide a link to the Creative Commons license, and indicate if changes were made. 


\section{References}

Abbink, K. (2004). Staff rotation as an anti-corruption policy: An experimental study. European Journal of Political Economy, 20(4), 887-906.

Abbink, K. (2006). Laboratory experiments on corruption. In S. Rose-Ackerman (Ed.), International handbook on the economics of corruption (pp. 418-438). Cheltenham: Edward Elgar.

Abbink, K., Dagupta, U., Gangadharan, L., \& Jain, T. (2014). Letting the briber go free: An experiment on mitigating harassment bribes. Journal of Public Economics, 111, 17-28.

Abbink, K., \& Hennig-Schmidt, H. (2006). Neutral versus loaded instructions in a bribery experiment. Experimental Economics, 9(2), 103-121.

Abbink, K., Irlenbusch, B., \& Renner, E. (2000). The moonlighting game: An experimental study on reciprocity and retribution. Journal of Economic Behavior \& Organization, 42(2), 265-277.

Abbink, K., Irlenbusch, B., \& Renner, E. (2002). An experimental bribery game. Journal of Law Economics and Organization, 18(2), 428-454.

Abbink, K., \& Wu, K. (2017). Reward self-reporting to deter corruption: An experiment on mitigating collusive bribery. Journal of Economic Behavior \& Organization, 133, 256-272.

Acemoglu, D. (2001). Inefficient redistribution. American Political Science Review, 95(3), 649-661.

Aidt, T., \& Shvets, J. (2012). Distributive politics and electoral incentives: Evidence from seven US state legislatures. American Economic Journal: Economic Policy, 4(3), 1-29.

Armantier, O., \& Boly, A. (2012). On the external validity of laboratory experiments on corruption. In D. Serra \& L. Wantchekon (Eds.), New advances in experimental research on corruption (pp. 117-144). Emerald: Bingley.

Armantier, O., \& Boly, A. (2013). Comparing corruption in the laboratory and in the field in Burkina Faso and in Canada. Economic Journal, 123(12), 1168-1187.

Azfar, O., \& Nelson, W., Jr. (2007). Transparency, wages, and the separation of powers: An experimental analysis of corruption. Public Choice, 130(3/4), 471-493.

Bandiera, O., Prat, A., \& Valletti, T. (2009). Active and passive waste in government spending: Evidence from a policy experiment. American Economic Review, 99(4), 1278-1308.

Banerjee, R. (2016). On the interpretation of bribery in a laboratory corruption: Moral frames and social norms. Experimental Economics, 19(1), 240-267.

Barr, A., \& Serra, D. (2009). The effect of externalities and framing on bribery in a petty corruption experiment. Experimental Economics, 12(4), 488-503.

Barr, A., \& Serra, D. (2010). Corruption and culture: An experimental analysis. Journal of Public Economics, 94(11-12), 862-869.

Barro, R. (1973). The control of politicians: An economic model. Public Choice, 14(1), 19-42.

Besley, T. (2006). Principled agents? The political economy of good government. Oxford: Oxford University Press.

Besley, T., \& Coate, S. (1998). Sources of inefficiency in a representative democracy: A dynamic analysis. American Economic Review, 88(1), 139-156.

Besley, T., \& Smart, M. (2007). Fiscal restraints and voter welfare. Journal of Public Economics, 91(3-4), $755-773$.

Bolton, G., \& Ockenfels, A. (2000). ERC: A theory of equity, reciprocity and competition. American Economic Review, 90(1), 166-193.

Büchner, S., Freytag, A., González, L., \& Güth, W. (2008). Bribery and public procurement: An experimental study. Public Choice, 137(1), 103-117.

Cameron, L., Chaudhuri, A., Erkal, N., \& Gangadharan, L. (2009). Propensities to engage in and punish corrupt behavior: Experimental evidence from Australia, India, Indonesia and Singapore. Journal of Public Economics, 93(7-8), 843-851.

Coate, S., \& Morris, S. (1995). On the form of transfers to special interests. Journal of Political Economy, 103(6), 1210-1235.

Escaleras, M., \& Lin, S. (2010). Freedom of information acts and public sector corruption. Public Choice, 145(3), 435-460.

Escaleras, M., Calcagno, P., \& Shughart, W. F., II. (2012). Corruption and voter participation: Evidence from US States. Public Finance Review, 40(6), 789-815.

Fearon, J. (1999). Electoral accountability and the control of politicians: Selecting good types versus sanctioning poor performance. In A. Przeworski \& S. Stokes (Eds.), Democracy, accountability, and representation (pp. 29-54). Cambridge, UK: Cambridge University Press.

Fehr, E., \& Schmidt, K. (1999). A theory of fairness, competition and cooperation. Quarterly Journal of Economics, 114(3), 817-868.

Ferejohn, J. (1986). Incumbent performance and electoral control. Public Choice, 50(1-3), 5-25. 
Ferraz, C., \& Finan, F. (2008). Exposing corrupt politicians: The effects of Brazil's publicly released audits on electoral outcomes. Quarterly Journal of Economics, 123(2), 703-745.

Ferraz, C., \& Finan, F. (2011). Electoral accountability on corruption: Evidence from the audits of local governments. American Economic Review, 101(4), 1274-1311.

Fischbacher, U. (2007). z-Tree: Zurich toolbox for ready-made economics experiments. Experimental Economics, 10(2), 171-178.

Fisman, R., \& Miguel, E. (2007). Corruption, norms, and legal enforcement: Evidence from diplomatic parking tickets. Journal of Political Economy, 115(6), 1020-1048.

Frey, B., \& Meier, S. (2004). Social comparisons and pro-social behavior: Testing conditional cooperation in a field experiment. American Economic Review, 94(5), 1717-1722.

Galasso, V., \& Nannicini, T. (2017). Political selection under alternative electoral rules. Public Choice, 171(3-4), 257-281.

Güth, W., Levatti, V., Sutter, M., \& van der Heijden, E. (2007). Leading by example with and without exclusion power in voluntary contribution experiments. Journal of Public Economics, 91(5-6), $1023-1042$.

Karahan, G., Coats, R. M., \& Shughart, W. F., II. (2006). Corrupt political jurisdictions and voter participation. Public Choice, 126(1-2), 87-106.

Kolstad, I., \& Wiig, A. (2016). How do voters respond to information on self-serving elite behavior? Evidence from a randomized survey experiment in Tanzania. CMI working paper no. 9.

Kunicová, J., \& Rose-Ackerman, S. (2005). Electoral rules and constitutional structures as constraints on corruption. British Journal of Political Science, 35(4), 573-606.

Lacombe, D., Coats, R. M., Shughart, W. F., II, \& Karahan, G. (2016). Corruption and voter turnout: A spatial econometric approach. Journal of Regional Analysis \& Policy, 46(2), 168-185.

Mondak, J. (1995). Competence, integrity, and the electoral success of congressional incumbents. The Journal of Politics, 57(4), 1043-1069.

Persson, T., \& Tabellini, G. (2002). Political economics: Explaining economic policy. Cambridge, MA: M.I.T. Press.

Serra, D., \& Wantchekon, L. (2012). New advances in experimental research on corruption. London: Emerald Books.

Weingast, B., Shepsle, K., \& Johnsen, C. (1981). The political economy of benefits and costs: A neoclassical approach to distributive politics. Journal of Political Economy, 89(4), 642-664.

Weisel, O., \& Shalvi, S. (2015). The collaborative roots of corruption. Proceedings of the National Academy of Science, 112(34), 10652-10656.

Winters, M., \& Weitz-Shapiro, R. (2013). Lacking information or condoning corruption: When do voters support corrupt politicians. Comparative Politics, 45(4), 418-436. 